\title{
ORGANIZATIONAL CULTURE AND ORGANIZATIONAL COMMITMENT: SERBIAN CASE
}

\author{
UDC: 005.7(497.11) \\ Original Scientific Paper
Siniša MITIĆ ${ }^{1}$, Jelena VUKONJANSKI ${ }^{2}$, Edit TEREK ${ }^{1}$, Bojana Gligorović ${ }^{2}$, Katarina ZORIĆ ${ }^{3}$ \\ ${ }^{1}$ University of Novi Sad, Faculty of Technical Sciences, Trg Dositeja Obradovića 6, 21000 Novi Sad, \\ Republic of Serbia \\ ${ }^{2}$ Republic of Serbia \\ ${ }^{3}$ Republic of Serbia \\ E-mail: katarina.zoric@tfzr.rs
}

Paper received: 02.04.2016.; Paper accepted: 13.04.2016.

\begin{abstract}
The paper presents the results of the impact of certain dimensions of organizational culture (Future Orientation, Power Distance, Human Orientation and Performance Orientation) on organizational commitment in companies in Serbia. Through a survey, responses were obtained from a total of $N=$ 400 middle managers from 129 companies. The results show a statistically significant correlation between the observed dimensions of organizational culture and organizational commitment dimensions. Also, there is a statistically significant predictive effect of certain dimensions of organizational culture on the dimensions of organizational commitment. The biggest influences on the dimensions of organizational commitment have dimensions Future Orientation - FO and Performance Orientation - PO. On the other hand, under the most affected dimension of organizational culture is the dimension of organizational commitment Organizational identification - OCM1.
\end{abstract}

Keywords: Organizational culture, GLOBE project, Organizational commitment, Serbia.

\section{INTRODUCTION}

Organizational culture has permeated through all the activities of the organization and it has a powerful impact on them. Organizational culture affects all the aspects of a company's business. Culture is not something that an organization has; culture is what the organization is (Pacanowsky \& O’Donnell-Trujillo, 1982). Organizational culture is one of the significant factors of employee satisfaction (Moynihan \& Pandey, 2007). Successful managers need to have an influence on employees and then organizational culture combines the values and attitudes of employees in the company (Weihrich \& Koontz, 1998). Managers need to understand the implications of diversity and the necessary skills to be successful in work and to be able to decide on a reasonable and sensitive cultural level (Javidan \& House, 2001). Organizations with more satisfied workers tend to be more effective than organizations with a small number of satisfied employees. One of the most important researches in this area (Judge et all., 2001), shows that the most affected are the factors relating to the organizational culture and personal determinants.

Of particular importance for this work are previous studies of the impact of organizational culture on organizational commitment of employees. According to (Acar, 2012) ensuring continuous and desirable work outcomes of employees lead to positive impact on organizational commitment of employees. In such circumstances, employees easier accept the organizational culture of the company. Research in the same references confirmed the existence of the positive effects of leadership and organizational culture on the organizational commitment, in the context of Turkish logistics industry. 
$\begin{array}{ll}\text { S. Mitić et al. } & \text { Organizational culture and organizational commitment: } \\ \text { Serbian case }\end{array}$

According to (Meyer et all.,2010), organizational commitment of employees may be increased by changing the organizational culture in the direction of person-organization (culture) fit. This is particularly useful to apply in the terms of the organizational changes. Similarly, the changeoriented leadership behavior has a positive relationship with organizational commitment (Özşahin et all., 2013). According to (Ellinger et al., 2013) making organizational investments in social capital positively affect organizational commitment, job performance, and organizational citizenship behavior of employees. In addition, coworkers support has different impact on organizational commitment, all depending on organizational culture (Limpanitgul et all., 2014).

At the level of individual countries, organizational commitment has a correlation with cultural values, such as individualism / collectivism, power distance (Meyer et al., 2012). Collectivistic values have a moderating influence on the relationship between person commitments and organizationallevel outcomes (Wasti \& Ca, 2008). Accordingly are the results of reference (Jaramillo et all., 2005), where it is shown that the correlations between organizational commitment and job performance are stronger at collectivist compared to individualistic cultures. Also, during the process of new product development often comes to the increase of organizational commitment, as expressed in particular in collectivistic cultures (Liang et all., 2014).

The research presented in this paper aims to determine the direction and intensity of the impact of certain dimensions of organizational culture on organizational commitment in companies in Serbia. This research may have practical importance, in terms of looking at options and making recommendations for managers on how to influence on raising the level of organizational commitment of employees.

\section{THEORY AND HYPOTHESES}

\section{Organizational Culture (GLOBE project)}

In this study, the level of the individual dimensions of organizational culture in companies in Serbia is determined according to the GLOBE project (The Global Leadership and Organizational Behavior Effectiveness Research Project). The main objective of the GLOBE project is to develop national measures and organizational culture and leadership that can be used in all cultures. This is a multi-phase multi-method project initiated by Robert House in 1993. It was involved in the project more than 170 researchers and scientists in the field of management from 62 countries from all major regions of the world (data according to House et all., 2004, since then, the number of participants has increased, but so far there is no official data on the number ).

According to (House et al., 1999; Dickson et all., 2000), the dimensions of organizational culture according to the GLOBE project are based on the research by several authors: Hofstede (1980, 2001), Hofstede \& Bond (1988), Kluckhohn \& Strodtbeck (1961), McClelland (1961, 1985), Putnam (1993). Culture dimensions of GLOBE project show that characterization of the national culture can be complex and include practices and behavior which are in progress (state that is) and the value of a firm belief of what culture should be (state how it should be) (Waldman et al., 2006). Culture dimensions of (national and organizational) GLOBE project are: (Javidan et all.,2004; House et al., 1999)

1. Uncertainty Avoidance is the degree to which members of the organization or society tend to avoid the uncertainty of relying on established social norms, rituals and bureaucratic practices.

2. Future oriented is the extent to which individuals in organizations or society are involved in the behavior oriented towards the future, such as planning, investing in the future and disposal of individual or collective gratification.

3. Power Distance is the degree to which members of the organization or society expect and agree that the power should be stratified and concentrated at higher levels of organization or country.

4. Collectivism I (Institutional Collectivism) is the degree to which organizational and social institutional practices encourage and reward the collective contribution of resources and collective action.

5. Humane Orientation is the extent to which individuals in organizations or society encourage and reward individuals because they are fair, altruistic, friendly, generous, caring and kind to others.

6. Performance Orientation is the degree to which an organization or society encourages and rewards the members of the group to improve performance and excellence. 
7. Collectivism II (In-Group) is a collectivism of a group, or the extent to which individuals express pride, loyalty and cohesion within the organization or family.

8. Gender Egalitarianism is the extent to which an organization or a company reduces gender differences while promoting gender equality.

9. Assertiveness is the extent to which individuals in organizations or society are assertive, and aggressive in social relations.

\section{Organizational commitment}

Organizational commitment is an active employee relationship with the organization, a relationship in which an individual is willing to give up something for the sake of the organization (Mowday et all., 1979). According to (Janićijević, 2008), organizational commitment can be seen as a certain expansion and a higher degree of job satisfaction, where employees feel a deep attachment to an organization or some of its members.

Organizational commitment is usually viewed through its dimensions. There are several models in defining the dimensions of organizational commitment (Cook \& Wall, 1980; Allen \& Meyer, 1990; Mowday et al., 1979). For the research in this paper, a model developed by Cook and Wall (1980) was used. This model has three dimensions:

1. Organizational identification (is applicable to the employees' sense of pride because his belonging to the organization).

2. Organizational involvement (is reflected in the desire and willingness of the employee to make additional efforts to fulfill the goals of the organization).

3. Organizational loyalty (includes a sense that the employee has an obligation to the organization and his willingness to remain in the organization even if another organization would offer him more money).

Based on the above considerations, in this paper, there are two hypotheses set:

H1: There are significant correlations between certain dimensions of organizational culture and organizational commitment dimensions.

$H 2$ : There is a statistically significant predictive effect of certain dimensions of organizational culture on the dimensions of organizational commitment.

\section{METHOD}

\section{Survey instruments (measures)}

Organizational culture is measured using the GLOBE questionnaire (House et al., 1999, 2002, 2004). This instrument measures 9 dimensions of organizational culture over 34 items. The research presented in this paper, includes four GLOBE dimensions of organizational culture: Future Orientation, Power Distance, Human Orientation and Performance Orientation. The respondents gave their answers via a seven-point Likert scale.

To measure organizational commitment an instrument developed by Cook and Wall (Cook \& Wall, 1980) was used. This instrument measures 3 dimensions of organizational commitment through 9 items. Dimensions are as follows: Organizational identification, Organizational involvement and Organizational loyalty. The respondents gave their answers via a five-point Likert scale.

\section{Participants and data collection}

The respondents were middle managers, employees in companies in Serbia. Middle managers completed the questionnaires, where an interview was used to support the process of filling out the questionnaire. A total of $\mathrm{N}=400$ middle managers from 129 companies completed the questionnaires.

\section{RESULTS}

Descriptive statistics of individual dimensions of organizational culture and organizational commitment dimensions is shown in Table 1. The table shows the names of dimensions, a short name for each dimension, mean, standard deviation and Cronbach's alpha for each dimension. Cronbach's alpha values vary in the range of $\alpha=0.739$ do $\alpha=$ 0.930 .

Coefficients of correlation between certain dimensions of organizational culture and commitment dimensions are given in Table 2 . Pearson correlation was used, whereby significant correlations are marked: $* p<0.05 ; * * p<0.01$. All observed correlations were statistically significant, and $* * \mathrm{p}<0.01$.

Predictive effects of certain dimensions of organizational culture (independent variables) on the dimensions of organizational commitment 
S. Mitić et al. Organizational culture and organizational commitment:

Serbian case

(dependent variables) were examined using results of regression analysis.

Multiple Regression analysis. Table 3 shows the

Table 1 Descriptive statistics for all dimensions

\begin{tabular}{|l|c|c|c|c|c|c|c|}
\hline \multicolumn{1}{|c|}{ Dimensions } & $\begin{array}{c}\text { Short } \\
\text { name }\end{array}$ & $\mathrm{N}$ & Min & Max & Mean & $\begin{array}{c}\text { Std. } \\
\text { Deviation }\end{array}$ & $\alpha$ \\
\hline Future Orientation & FO & 400 & 1.00 & 7.00 & 3.8225 & 1.61530 & .817 \\
\hline Power Distance & PD & 400 & 1.00 & 7.00 & 4.3233 & 1.59971 & .801 \\
\hline Human Orientation & HO & 400 & 1.00 & 7.00 & 4.3556 & 1.59826 & .930 \\
\hline Performance Orientation & PO & 400 & 1.00 & 7.00 & 4.1412 & 1.40266 & .806 \\
\hline Organizational identification & OCM1 & 400 & 1.00 & 5.00 & 3.7425 & .96619 & .793 \\
\hline Organizational involvement & OCM2 & 400 & 1.00 & 5.00 & 4.0942 & .83222 & .784 \\
\hline Organizational loyalty & OCM3 & 400 & 1.00 & 5.00 & 3.1558 & 1.15393 & .739 \\
\hline
\end{tabular}

Table 2 Pearson coefficients of correlation between certain dimensions of organizational culture and organizational commitment dimensions

\begin{tabular}{|c|c|c|c|}
\hline & OCM1 & OCM2 & OCM3 \\
\hline FO & $.467^{* *}$ & $.300^{* *}$ & $.293^{* *}$ \\
\hline PD & $-.370^{* * *}$ & $-.258^{* *}$ & $-.244^{* *}$ \\
\hline HO & $.362^{* *}$ & $.220^{* *}$ & $.240^{* *}$ \\
\hline PO & $.468^{* *}$ & $.277^{* * *}$ & $.288^{* *}$ \\
\hline
\end{tabular}

Table 3 Regression analysis (Predictors: dimensions of organizational culture; Dependent Variable: dimensions of organizational commitment)

\begin{tabular}{|c|c|c|c|c|c|c|c|}
\hline \multirow{3}{*}{ Dependent } & & & & & \multirow{3}{*}{$\mathrm{R}^{2}$} & \multirow{3}{*}{$\mathrm{F}$} & \multirow{3}{*}{ Sig } \\
\hline & $\mathrm{FO}$ & PD & $\mathrm{HO}$ & $\mathrm{PO}$ & & & \\
\hline & \multicolumn{4}{|c|}{$\beta$} & & & \\
\hline OCM1 & .248 & -.062 & .051 & .254 & .276 & 37.610 & .000 \\
\hline OCM2 & .169 & -.089 & .015 & .118 & .109 & 12.115 & .000 \\
\hline OCM3 & .148 & -.056 & .052 & .138 & .109 & 12.086 & .000 \\
\hline
\end{tabular}

\section{DISCUSSION}

Descriptive statistics (Table 1) show that the mean values of the observed dimensions of organizational culture are close to average (4.00). Dimension Power Distance - PD has a slightly higher mean value. It is not surprising, given that Serbia is a country with high power distance (Vukonjanski et all., 2012; Nikolić et all., 2014). The result obtained for power distance in this paper can even be considered as good. The results of mean values for the dimensions of Human Orientation - HO and Performance Orientation PO can be considered as positive, they are above average. As the weakest result the mean value for the dimension Future Orientation - FO can be considered. The value is below the average. This shows that in Serbia plans are not made to be long term ones and that the top management is mainly making short term plans and is focused on "small" victories.
As for the mean values for the dimensions of organizational commitment, it can be concluded that they are quite high, especially for the dimension Organizational involvement - OCM2. A dilemma occurs here, whether employees are really ready to invest additional effort for their company, or the situation is such that it is expected from the employees? The transition conditions that are still present in the companies in Serbia, as well as high unemployment, are leading the employees in the position that they are easily convertible in the company. So, employees accept more responsibilities and obligations, and now they even begin to consider this as normal, which is also true for employers. Dimension Organizational loyalty OCM3 has the lowest value. This is logical if one takes into account the low level of wages and low living standard of people in Serbia. In such circumstances, it is difficult to expect a high employee loyalty toward a company. If provided by a better alternative, many people take advantage of such a chance. 
All the correlations between certain dimensions of organizational culture and commitment dimensions are statistically significant (Table 2). Dimension Power Distance - PD achieved a statistically significant negative correlation, as expected. In this way hypothesis H1 is confirmed. The biggest influence on the dimensions of organizational commitment achieves the dimension Future Orientation - FO and Performance Orientation PO. It is obvious that the employees highly value planned approach to solving problems, organized processes and procedures, fair promotion system, performance improving. Employees are aware that these are the prerequisites for long-term survival of the company in terms of competitiveness and uncertain market. Therefore, employees give their best on the job if they feel that it makes sense and their work will lead to a good result and that it will lead to a benefit for the company. Dimension Human Orientation - $\mathrm{HO}$ also has a positive and statistically significant impact on the dimension organizational commitment, but the correlation is somewhat lower. Similar is with the correlation of dimension Power Distance - PD, which are negative and statistically significant, but they are also slightly lower. The explanation for these results can be found by considering a fictitious extremely bad situation for the company: it can be assumed that in such circumstances, employees are more willing to accept an autocratic leader with high power distance and low guidance toward people, but the absence of a strategy, prospects and quality of work. High performance, achieved through planning the future take precedence over the human aspects of management. Employees are obviously aware of the danger of losing the competitive race.

From the three dimensions of organizational commitment, the strongest correlation with the observed dimensions of organizational culture, achieves dimension Organizational identification OCM1. Dimension Organizational involvement OCM2, as explained above, is in a significant part influenced by the general conditions in companies in Serbia. It is similar with the dimension Organizational loyalty - OCM3. Thus, the dimensions of organizational culture can have the greatest impact on the pride of the employee because of belonging to an organization. This aspect is the least affected by external factors.

Table 3 shows the results of the regression analysis. The organizational culture dimensions are independent variables, while dimensions of organizational commitment are dependent variables. The results show that, of the organizational culture dimensions, statistically significant predictive effect have dimensions Future Orientation - FO and, somewhat less, dimension Performance Orientation - PO. In Table 3 , can also be seen the corrected determination index $\mathrm{R}^{2}$. At all dependent variables (dimensions of organizational commitment) there were statistically significant value determination indexes $\mathrm{R}^{2}$. Accordingly, it can be concluded that there is a statistically significant predictive effect of the observed dimensions of organizational culture on the dimensions of organizational commitment. In this way the hypothesis $\mathrm{H} 2$ is confirmed. The highest value of $\mathrm{R}^{2}$ exist at dimension Organizational identification - OCM1. On this basis, it is easy to perceive that all the results of regression analysis are completely consistent with the results of correlation analysis. So, all reasons given at the results of correlation analysis are valid for the results of the regression analysis.

\section{CONCLUSION}

From the dimensions of organizational culture, the lowest mean value has dimensions Future Orientation - FO. From the dimensions of organizational commitment a high average value has the dimension Organizational involvement OCM2, while the lowest mean value has the dimension Organizational loyalty - OCM3. Managers should devote more attention to planning in advance. Similarly, managers should act to increase organizational loyalty of the employees. However, this is not easy, given that the loyalty is under the influence of external factors, such as low pay, low living standards and high unemployment. What managers can do is to do their job better, because among other things the company would be able to provide better employee benefits, but also to motivate and encourage their subordinates.

Both hypotheses set at the beginning of the paper, are confirmed. So, there are statistically significant correlations between certain dimensions of organizational culture and organizational commitment dimensions. Also, there is a statistically significant predictive effect of certain dimensions of organizational culture on the dimensions of organizational commitment. The biggest influence on the dimensions of organizational commitment have dimensions Future Orientation - FO and Performance Orientation - PO. On the other hand, the most affected dimensions of organizational culture is the 
$\begin{array}{ll}\text { S. Mitić et al. } & \text { Organizational culture and organizational commitment: } \\ \text { Serbian case }\end{array}$

dimension of organizational commitment Organizational identification - OCM1.

Overall, it can be concluded that organizational culture definitely has a positive impact on organizational commitment. If managers want greater employee commitment, they should work to improve the organizational culture of their company. In this way, at the same time the conditions are provided, not only for increasing the degree of organizational commitment, but also for improving a number of other organizational and business performance.

\section{ACKNOWLEDGEMENT}

This paper is a part of the research project "The impact of organizational culture and leadership on certain organizational and business performance in companies in Serbia", which is funded by the Provincial Secretariat for Science and Technological Development within the "Right for first chance".

\section{REFERENCES}

Acar, A. Z. (2012). Organizational Culture, Leadership Styles and Organizational Commitment in Turkish Logistics Industry. Social and Behavioral Sciences, 58(12), 217-226.

Allen N. J., \& Meyer, J. P. (1990). The Measurement and Antecedents of Affective, Continuance and Normative Commitment to the Organization. Journal of Occupational Psychology, 63, 1-18.

Cook, J., \& Wall, T. (1980). New Work Attitude Measures of Trust, Organizational Commitment and Personal Need Non-Fulfilment. Journal of Occuptational Psychology, 53, 39-52.

Dickson, M. W., Aditya, R. N., \& Chhokar, J. S. (2000). Definition and Interpretation in Cross-Cultural Organizational Culture Research: Some Pointers From the GLOBE Research Program. Ashkanasy, N.M.

Wilderom, C. P. M., \& Peterson, M. F. Handbook of organizational culture and climate Thousand Oaks, CA: Sage Publications, Inc.

Ellinger, A.E., Musgrove, C.F., Ellinger, A.D., Bachrach, D.G., Baş A.B.E., \& Wang, Y.L. (2013). Influences of organizational investments in social capital on service employee commitment and performance. Journal of Business Research, 66(8), 1124-1133.

Hofstede, G., \& Bond, M.H. (1988). The Confucius connection. From cultural roots to economic growth. Organizational Dynamics, 16, 4-21.
Hofstede, G. (1980). Culture's Consequences International Differences in Work-Related Values. Abridged Edition, Sage: Newbury Park.

Hofstede, G. (2001). Culture's Consequences, Comparing Values, Behaviors, Institutions, and Organizations Across Nations. Thousand Oaks CA: Sage Publications.

House, R. J., Hanges, P. J., Ruiz-Quintanilla, S. A., Dorfman, P. W., Falkus, S. A., \& Ashkanasy, N. M. (1999). Cultural influences on leadership and organizations: Project Globe. In W. H. Mobley, M. J. Gessner and V. Arnold (Ed.), Advances in Global Leadership 2 ed. (171-233) Bingley, UK: Emerald Group Publishing Ltd.

House, R.J., Javidan, M., Hanges, P., \& Dorfman, P. (2002). Understanding Cultures and Implicit Leadership Theories Across the Globe: An Introduction to Project GLOBE. Journal of World Business, 37(1), 3-10.

House, R.J., Hanges, P.J., Javidan, M., Dorfman, P.W., \& Gupta. V. (2004). Leadership, culture, and organizations: The GLOBE study of 62 societies. Thousand Oaks, CA: Sage.

Janićijević, N. (2008). Organiyational behavior. Belgrade. (In Serbian): Data Status.

Jaramillo, F., Mulki, J.P., \& Marshall, G.W. (2005). A meta-analysis of the relationship between organizational commitment and salesperson job performance: 25 years of research. Journal of Business Research, 58(6), 705-714.

Javidan, M., \& House, R.J. (2001). Cultural Acumen for the Global Manager: Lessons from Project GLOBE. Organizational Dynamics, 29(4), 289-305.

Javidan, M., House, R.J., \& Dorfman, P.W. (2004). A Nontechnical Summary of GLOBE Findings. In R.J. House, P.J. Hanges, M. Javidan, P.W. Dorfman, and V. Gupta (Eds.), Culture, Leadership, and Organizations: The GLOBE Study of 62 Societies (29-48). Thousand Oaks, CA: Sage.

Judge, T.A., Thoresen, C.J., Bono, J.E., \& Patton, G.K. (2001). The Job Satisfaction - Job Performance Relationship: a Qualitative and Quantitative Review. Psychological Bulletin, 127, 376-407.

Kluckhohn, F., \& Strodtbeck, F.L. (1961). Variations in value orientations. Evanston, IL: Row, Peterson.

Liang, B., Kale, S.H., \& Cherian, J. (2014). Is the future static or dynamic? The role of culture on escalation of commitment in new product development. Industrial Marketing Management, 43(1), 155-163.

Limpanitgul, T., Boonchoo, P., \& Photiyarach, S. (2014). Coworker support and organisational commitment: A comparative study of Thai employees working in Thai and American airlines. Journal of Hospitality and Tourism Management, 21, 100-107.

McClelland, D.C. (1961). The achieving society. Princeton, NJ: Van Nostrand.

McClelland, D.C. (1985). Human motivation. Glenview, IL: Scott, Foresman. 
Meyer, J.P., Hecht, T.D., Gill, H., \& Toplonytsky, L. (2010). Person-organization (culture) fit and employee commitment under conditions of organizational change: A longitudinal study. Journal of Vocational Behavior, 76(3), 458-473.

Meyer, J.P., Stanley, D.J., Jackson, T.A., McInnis, K.J., Maltin, E.R., \& Sheppard, L. (2012). Affective, normative, and continuance commitment levels across cultures: A meta-analysis. Journal of Vocational Behavior, 80(2), 225-245.

Mowday, R.T., Steers, R.M., \& Porter, R.W. (1979). The Measurement of Organizational Commitment. Journal of Vocational Behavior. 14, 224-247.

Moynihan, D.P., \& Pandey, S.K. (2007). Finding workable levers over work motivation: Comparing job satisfaction, job involvement, and organizational commitment. Administration \& Society, 39(7), 803 832.

Nikolić. M., Vukonjanski, J., Nedeljković, M., Hadžić, O., \& Terek, E. (2014). The relationship between communication satisfaction, emotional intelligence and the GLOBE organizational culture dimensions of middle managers in Serbian organizations. Journal for East European Management Studies, 19(4), 387-412.

Özşahin, M., Zehir, C., Acar A.Z., \& Sudak, M.K (2013). The Effects of Leadership and Market
Orientation on Organizational Commitment. Social and Behavioral Sciences, 99(6), 363-372.

Pacanowsky, M., \& O'Donell-Trujillo, N. (1982). Communication and organizational culture. The Western Journal of Speech Communication, 46(2), 115-130.

Putnam, R.D. (1993). Making democracy work. Princeton, NJ: Princeton University Press.

Waldman, D.A., de Luque, M.S., Washburn, N., House, R.J. et.all (2006). Cultural and leadership predictors of corporate social responsibility values of top management: a GLOBE study of 15 countries. Journal of International Business Studies, 37, 823837.

Wasti, S.A., \& Ca, Ö. (2008). Affective and normative commitment to organization, supervisor, and coworkers: Do collectivist values matter? Journal of Vocational Behavior, 73(3), 404-413.

Vukonjanski, J., Nikolić, M., Hadžić, O., Terek, E., \& Nedeljković, M. (2012). Relationship between GLOBE organizational culture dimensions, job satisfaction and leader-member exchange in Serbian organizations. Journal for East European Management Studies, 17(3), 333-368.

Weihrich, H., \& Koontz, H. (1998). Management (11th ed.), Zagreb: Mate.

\title{
ORGANIZACIONA KULTURA I ORGANIZACIONA POSVEĆENOST: SLUČAJ SRBIJE
}

\begin{abstract}
U radu su predstavljeni rezultati istraživanja uticaja pojedinih dimenzija organizacione kulture (orjentacija ka budućnosti, distanca moći, orjentacija ka ljudima, orjentacija ka performansama) na organizacionu posvećenost, u preduzećima u Srbiji. Putem ankete, dobijeni su odgovori od ukupno $N=400$ srednjih menadžera iz 129 preduzeća. Rezultati pokazuju da postoje statistički značajne korelacije između posmatranih dimenzija organizacione kulture i dimenzija organizacione posvećenosti. Takođe, postoji statistički značajno prediktivno dejstvo pojedinih dimenzija organizacione kulture na dimenzije organizacione posvećenosti. Najveći uticaj na dimenzije organizacione posvećenosti imaju dimenzije orjentacija ka budućnosti - FO i orjentacija ka performansama - PO. S druge strane, pod najvećim uticajem dimenzija organizacione kulture, nalazi se dimenzija organizacione posvećenosti organizaciona identifikacija - OCM1.
\end{abstract}

Ključne reči: Organizaciona kultura, GLOBE projekat, Organizaciona posvećenost, Srbija. 